Research Article

\title{
Spray technology for deposition of droplets on coffee leaves and fruits ${ }^{1}$
}

Renan Zampiróli ${ }^{2}$, Cleyton Batista de Alvarenga ${ }^{2}$, Matheus Vilhena Parenti ${ }^{3}$, João Paulo Arantes Rodrigues da Cunha ${ }^{4}$, Fernando Juari Celoto ${ }^{4}$, Paula Cristina Natalino Rinaldi ${ }^{2}$, Robson Shigueaki Sasaki ${ }^{5}$

\section{ABSTRACT}

The correct deposition of spray along the canopy is important for the phytosanitary control in coffee plants; however, the structure of the plant makes this distribution difficult. This study aimed to evaluate the deposition of a tracer on leaves and fruits in coffee cultivation, with respect to the application rate and type of hydraulic nozzle, as well as the use of an electrostatic spraying system. A hydropneumatic sprayer was used, with hydraulic nozzles of empty conical jet of the series TVI (coarse droplets with air induction) or JA (fine droplets), at rates of 200 and $400 \mathrm{~L} \mathrm{ha}^{-1}$. An electrostatic system, with SPE-2 nozzle and rate of $200 \mathrm{~L} \mathrm{ha}^{-1}$, was also evaluated. The deposition of the tracer on leaves and fruits of the upper, middle and lower thirds of the trees, as well as the losses to the ground in the canopy projection, were quantified using spectrophotometry. The results indicated that the electrostatic application provides a greater deposition on leaves of the upper third than the hydropneumatic application, regardless of the application rate. The use of the TVI nozzle results in a greater deposition on the fruits of the middle third and a greater loss to the ground than the JA nozzle. Although an application rate of $400 \mathrm{~L} \mathrm{ha}^{-1}$ results in a greater deposition on the fruits of the middle third than an application rate of $200 \mathrm{~L} \mathrm{ha}^{-1}$, it also causes a greater loss to the ground.

KEYWORDS: Coffea arabica, hydraulic nozzles, hydropneumatic sprayer.

\section{INTRODUCTION}

Coffee growers have only a few options of spray nozzles for the application of phytosanitary products in coffee cultivation. The technology used in sprayers in Brazilian coffee plantations is poorly developed. The application rate used in the phytosanitary management of coffee typically

\section{RESUMO}

Tecnologia de aplicação para

deposição de gotas em folhas e frutos de café

Para o sucesso do controle fitossanitário no cafeeiro, é importante uma correta deposição de calda ao longo do dossel. Contudo, a estrutura da planta dificulta essa distribuição. Objetivouse avaliar a deposição de um traçador em folhas e frutos, na cultura do café, em função da taxa de aplicação e do tipo de ponta de pulverização, bem como do emprego de um sistema de pulverização eletrostática. Utilizou-se pulverizador hidropneumático com pontas hidráulicas de jato cônico vazio, da série TVI (gotas grossas com indução de ar) e JA (gotas finas), em taxas de 200 e $400 \mathrm{~L} \mathrm{ha}^{-1}$. Também foi avaliado um sistema eletrostático, com ponta SPE-2 e taxa de $200 \mathrm{~L} \mathrm{ha}^{-1}$, instalado no mesmo pulverizador. Foram determinadas a deposição do traçador em folhas e frutos dos terços superior, médio e inferior das plantas, bem como as perdas para o solo na projeção da copa, mediante quantificação por espectrofotometria. Os resultados indicaram que a aplicação eletrostática proporciona maior deposição nas folhas do terço superior, em relação à aplicação hidropneumática, independentemente da taxa de aplicação. A ponta TVI produz maior deposição nos frutos do terço médio e maior perda para o solo, em relação à ponta JA. A taxa de aplicação de $400 \mathrm{~L} \mathrm{ha}^{-1}$ promove maior deposição nos frutos do terço médio, em relação à de $200 \mathrm{~L} \mathrm{ha}^{-1}$, mas também causa maior perda para o solo.

PALAVRAS-CHAVE: Coffea arabica, pontas hidráulicas, pulverizadores hidropneumáticos.

varies between 200 and 1,500 $\mathrm{L} \mathrm{ha}^{-1}$, depending on the target. Although knowledge of the biometrics of cultivars is necessary for successful applications, studies on this topic are limited or nonexistent (Gil \& Escola 2009, Sinha et al. 2020).

Coffee growers, associations, cooperatives and others involved in the sector have sought sustainability through professionalization in cost

\footnotetext{
${ }^{1}$ Received: Nov. 27, 2020. Accepted: Feb. 24, 2021. Published: Apr. 16, 2021. DOI: 10.1590/1983-40632021v5166806.

${ }^{2}$ Universidade Federal de Uberlândia, Monte Carmelo, MG, Brasil.E-mail/ORCID: renanzampiroli@ufu.br/0000-0002-5082-9111; cleytonalvarenga@ufu.br/0000-0002-0431-6171; paularinaldi@ufu.br/0000-0001-9290-9040.

${ }_{3}^{3}$ Syngenta, Vilhena, RO, Brasil. E-mail/ORCID: matheus.parenti@syngenta.com/0000-0002-8931-7818.

${ }^{4}$ Universidade Federal de Uberlândia, Uberlândia, MG, Brasil.

E-mail/ORCID: jpcunha@ufu.br/0000-0001-8872-3366; fceloto@ufu.br/0000-0003-2583-1372.

${ }^{5}$ Instituto Federal de Minas Gerais, Bambuí, MG, Brasil. E-mail/ORCID: robson.sasaki@ifmg.edu.br/0000-0001-8262-5781.
} 
management, certification or adoption of good agricultural practices. However, the various biotic and abiotic challenges affecting coffee crops make this difficult (Souza et al. 2020). Nonetheless, coffee cultivation has significant impacts on the economic and social development of Brazil (Conab 2020). In particular, the Brazilian Savanna region of the Minas Gerais state stands out for its production capacity, crop adaptation and mechanization of operations.

Empty conical jet hydraulic nozzles are typically used for the control of insects in coffee cultivation, with production of ultrafine and fine droplets, the former being more prone to drift (Grella et al. 2020). However, they provide a large coverage, high droplet density and high degree of product penetration (Tripathi et al. 2020). Conversely, the use of hydraulic nozzles that produce coarse droplets can reduce drift. Coarse droplets are also related to reduced evaporation. However, their use is not common in the management of insects in coffee cultivation and is therefore rarely studied.

The application technology widely used to obtain fine and very fine droplets is based on conventional hydropneumatic sprays (Crause et al. 2020, Melo et al. 2020). The installation of an electrostatic kit allows the spray to be charged with electrons through a charge induction system, which generates an electric field and attracts the droplets to the leaf surface, potentially increasing the leaf deposition (Salcedo et al. 2020).

Thus, it is important to determine the spray deposition along the coffee canopy using different systems to optimize the effectiveness of phytosanitary treatments. In addition to energizing the droplets, the deposition or retention of products on the target is affected by the spray nozzle and application rate (Melo et al. 2020), leaf volume (An et al. 2020), crown structure (Sinha et al. 2020) and leaf surface (Li et al. 2020). Thus, this study aimed to evaluate the deposition of a tracer dye on leaves and fruits in coffee cultivation, with respect to the application rate and hydraulic nozzle, as well as the use of an electrostatic spraying system.

\section{MATERIAL AND METHODS}

The experiment was conducted at the Japão farm, in Estrela do Sul, Minas Gerais state, Brazil (18 43'01.42"'S, 4747'11.30'W and $997 \mathrm{~m}$ above the sea level), in December 2018.

An Arbo 360 Montana sprayer (São José dos Pinhais, Paraná, Brazil) was employed in the conventional hydropneumatic application. The sprayer contained six nozzle holders in each bar, and the same sprayer was used in the electrostatic application with an electrostatic kit composed of six nozzles, which was developed and marketed by Electrostatic Spraying Systems (Sistema de Pulverização Eletrostático - SPE, Porto Alegre, Rio Grande do Sul, Brazil). The sprayer had a tank with capacity of $300 \mathrm{~L}$, a membrane-type hydraulic pump with flow of $40 \mathrm{~L} \mathrm{~min}^{-1}$, a fan with diameter of $615 \mathrm{~mm}$ generating an air volume rate of $14,900 \mathrm{~m}^{3} \mathrm{~h}^{-1}$, and nine blades set at a fixed angle.

The sprayer was coupled to a tractor threepoint hitch, with the center of the fan at $1,070 \mathrm{~mm}$ above the ground. The influence of the rotation direction of the fan, which depended on the position of the blades, was minimized by using only the right side of the bar to standardize the airflow direction, being applied on both sides of the plants. The sprayer was activated by a Massey Ferguson tractor (model 275, Canoas, Rio Grande do Sul, Brazil) with rated power of $55.16 \mathrm{~kW}$ and $4 \times 2$ traction.

The experiment was conducted with a randomized block design, in a $2 \times 2+1$ factorial scheme, involving two spray volumes (200 and $400 \mathrm{~L} \mathrm{ha}^{-1}$ ), two spray nozzles (TVI-80-0075 and JA-1) and one additional treatment (electrostatic system, $200 \mathrm{~L} \mathrm{ha}^{-1}$ and SPE-2 nozzle), with six replicates (Table 1). Both the TVI-80-0075 nozzle

Table 1. Description of treatments and operational characteristics.

\begin{tabular}{ccccl}
\hline Application rate $\left(\mathrm{L} \mathrm{ha}^{-1}\right)$ & Pulverization nozzle & Speed $\left(\mathrm{km} \mathrm{h}^{-1}\right)$ & Working pressure $(\mathrm{kPa})$ & Droplet size* \\
\hline 400 & TVI-80-0075 & 4.6 & 931 & Coarse \\
400 & JA-1 & 4.6 & 1,034 & Fine \\
200 & JA-1 & 5.8 & 414 & Fine \\
200 & TVI-80-0075 & 6.9 & 517 & Coarse \\
200 & SPE-2 & 6.9 & 861 & Very fine \\
\hline
\end{tabular}

* Source: Máquinas Agrícolas Jacto S. A. (2020). 
(Albuz, Evreux, France) with air induction and the JA-1 nozzle (Jacto, Pompeia, São Paulo, Brazil) produce an empty conical jet. Duplicators were required in both hydraulic nozzles to achieve the required spray volumes, with a total of 12 nozzles. In the additional treatment, the SPE- 2 empty conical jet nozzle was used with an electrostatic kit mounted on the bar. An electric field was formed at the base of the spray jet in this treatment owing to the electrification of the ring present in the nozzle.

The experimental area contained 'Topázio' coffee cultivar of 7 years of age, with a spacing of $3.8 \times 0.7 \mathrm{~m}$, totaling 3,760 plants $\mathrm{ha}^{-1}$, with fruits classified as green-cane stage. The plot consisted of 57 plants, corresponding to a length of $40 \mathrm{~m}$, with 25 plants considered useful and 16 at each end considered as border plants. The plots were set $40 \mathrm{~m}$ apart, with $7.6 \mathrm{~m}$ between rows to reduce drift effects.

Leakage loss was determined using two Petri dishes with area of $63.59 \mathrm{~cm}^{2}$, positioned on the ground under the projection of the coffee canopy, spaced at 0.25 and $0.5 \mathrm{~m}$ from the orthotropic branch, using a methodology adapted from Gitirana Neto et al. (2016).

Deposition on leaves and fruits was evaluated by absorbance spectrophotometry, using a method adapted from Miranda et al. (2012). The spray consisted of water and Blue Bright food coloring (Duas Rodas, Jaraguá do Sul, SC, Brazil), which is internationally cataloged by the Federal Food, Drug and Cosmetic Act as FD\&C Blue n. 1 (Miranda et al. 2012), at a dose of $500 \mathrm{~g} \mathrm{ha}^{-1}$.

Two leaves and five fruits between the orthotropic branch and the end of the plagiotropic branch in the upper, middle and lower thirds of the tree - corresponding to heights of 2.4, 1.2 and $0.6 \mathrm{~m}$, in relation to the ground, respectively - were collected randomly at $20 \mathrm{~min}$ after spraying. These methods were adapted from Sasaki et al. (2015) for leaves and Miranda et al. (2012) for fruits.

After the application, the leaf and fruit samples were labeled, packed in plastic bags and transported in a polystyrene box with thermal and light insulation. A total of $30 \mathrm{~mL}$ of distilled water was added to each plastic bag in the laboratory. The plastic bags were shaken for $30 \mathrm{~s}$, to homogenize the dye in the samples. The liquid was then transferred to plastic cups, stored in a cool place, and isolated from light for $24 \mathrm{~h}$ prior to reading the absorbance via the spectrophotometer.
The absorbance was determined using a Femto spectrophotometer (model $600 \mathrm{Plus}^{\mathrm{TM}}$, São Paulo, Brazil) and $3.5 \mathrm{~mL}$ glass cuvettes, with an optical path of $10 \mathrm{~mm}$. A tungsten-halogen lamp was used to determine the absorbance at $630 \mathrm{~nm}$, i.e., the blue dye detection range.

The leaf area was measured using a Liquor equipment (model LI 3100C, Lincoln, Nebraska, United States). The area of the two leaves sampled was recorded for later determination of the deposition rates. The deposition on the fruit was determined volumetrically using the water displacement method in a graduated cylinder $(25 \mathrm{~mL})$ by immersing the fruit in a known volume of water, resulting in a density of $0.9977 \mathrm{~g} \mathrm{~mL}^{-1}$.

The calibration equation was determined depending on the dye, based on a standard solution at the application concentration. The absorbance data were transformed into concentration $\left(\mu \mathrm{g} \mathrm{L}^{-1}\right)$ (Melo et al. 2020). The mass of dye retained on the coffee leaf was determined using the initial concentration of the spray and the dilution volume of the samples. The total deposit was divided by the leaf area of each sample to obtain the amount of dye per unit leaf area, Petri dish area and fruit volume.

The meteorological conditions during the applications were monitored using an Instrutherm portable digital thermo-hygro-anemometer (model AD-250, São Paulo, Brazil). The temperature varied between 25 and $31^{\circ} \mathrm{C}$, the relative humidity between 60 and $67 \%$, and the wind speed between 3 and $7 \mathrm{~km} \mathrm{~h}^{-1}$.

A statistical analysis was performed using the R statistical software (R Core Team 2019). The data satisfied the assumption of residual normality by the Shapiro-Wilk (W) test and the homogeneity of variances by the Anscombe and Tukey test. The Dunnett's test was performed to compare the means with the additional treatment. All the tests were conducted at $5 \%$ of probability.

\section{RESULTS AND DISCUSSION}

The interaction of the application rate and spray nozzle factors with the additional treatment (electrostatic spray) was significant in the deposition of the spray on the leaves at the upper third of the tree, but the nozzles and spray volumes did not interfere with the deposition on leaves. In the middle third (where several fruits were present), different spray 
nozzles and application rates resulted in different dye deposition amounts. The losses to the ground at the canopy projection were also affected by the application rate and spray nozzles (Table 2).

The deposition resulting from the application of fine and coarse droplets on the leaves did not differ. Thus, coarse droplets with air induction can be used for the management of insects and diseases that target the leaves. This is uncommon in the phytosanitary management of coffee, where the use of very fine and fine droplets predominates. According to $\mathrm{Gu}$ et al. (2020), the airflow generated by the spray turbine probably caused the deposition of the fine and coarse droplets over longer distances, as in the upper canopy.

The application of spray to control harmful agents that attack the leaves is continuously necessary, as some insects and diseases attack coffee trees throughout the year. For this reason, having options for spray nozzles and knowing the advantages of working with different droplet sizes can promote good agricultural practices among coffee growers. Souza Júnior et al. (2017) did not identify any differences in the deposition in coffee crops at different application rates. It is likely that, as stated by Salcedo et al. (2020), differences in the leaf densities or plant architectures are the primary factors affecting the deposition along the canopy.

The result of the interaction between the factorial and the additional treatment indicated that the electrostatic application resulted in a 47.1 and $70.5 \%$ greater deposition than that of the TVI nozzle and a 61.7 and $64.7 \%$ greater deposition than that of the JA nozzle in the upper third of the trees, at rates of 200 and $400 \mathrm{~L} \mathrm{ha}^{-1}$, respectively (Table 3).

The deposition on the upper third of the trees is a challenge for the application of fungicides and
Table 3. Dye deposition on the leaves of the upper third of coffee trees, according to the spray nozzle and application rate.

\begin{tabular}{lcc}
\hline \multirow{2}{*}{ Nozzle } & \multicolumn{2}{c}{ Application rate $\left(\mathrm{L} \mathrm{ha}^{-1}\right)$} \\
\cline { 2 - 3 } & \multicolumn{2}{c}{200} \\
\cline { 2 - 3 } & \multicolumn{2}{c}{ Deposition $\left(\mu \mathrm{L} \mathrm{cm}^{-2}\right)$} \\
\hline TVI-80-0075 & $1.8 \alpha^{*}$ & $1.0 \alpha$ \\
JA-1 & $1.2 \alpha$ & $1.3 \alpha$ \\
\hline SPE-2 & \multicolumn{2}{c}{9.4} \\
\hline CV $(\%)$ & \multicolumn{2}{c}{98} \\
* Means followed by the Greek letter $\alpha$ differ from the additional treatment by the
\end{tabular}
Dunnett's test $(\mathrm{p}>0.05)$.

insecticides on coffee trees. A longer distance from the spray nozzle to the plant favors the droplet evaporation, resulting in less leaf deposition. Sinha et al. (2020) also observed a difference in the spray deposition along the canopy. A low leaf density allows the droplets to pass through the canopy, thus not being deposited on the leaves, what also hinders the target coverage. Similarly, Campos et al. (2020) found that higher vegetative volumes increase the deposition of droplets along the canopy.

As stated by the manufacturer, the SPE-2 nozzle produces very fine droplets, according to the criteria of the ASAE S572.1 standard (ASAE 2009). These droplets are adequately sized for induction by electrical charges and attraction to the target, in agreement with Khatawkar et al. (2020) and Tessum \& Raynor (2021), who stated that the charge is inversely proportional to the droplet size. The resulting attraction increases the deposition on leaves and reduces the number of droplets that pass over the crown. On average, the electrostatic application results in a $38.0 \%$ higher deposition rate than the hydropneumatic application in the upper third of the plant. Sasaki et al. (2013) and Salcedo et al. (2020)

Table 2. Analysis of variance results for deposition of spray on leaves and fruits and on Petri dishes on the ground.

\begin{tabular}{|c|c|c|c|c|c|c|c|c|c|}
\hline \multirow{3}{*}{$\begin{array}{l}\text { Source of } \\
\text { variation }\end{array}$} & \multirow{3}{*}{ DF } & \multicolumn{8}{|c|}{ Medium square } \\
\hline & & \multicolumn{3}{|c|}{ Leaves in the third- } & \multicolumn{3}{|c|}{ Fruits in the third } & \multicolumn{2}{|c|}{ Petri dish } \\
\hline & & Higher & Medium & Lower & Higher & Medium & Lower & External & Internal \\
\hline Volume (V) & 1 & $0.7^{\mathrm{ns}}$ & $1.9^{\text {ns }}$ & $0.8^{\mathrm{ns}}$ & $1,341.2^{\mathrm{ns}}$ & $2,748.0^{*}$ & $1,521.7^{\mathrm{ns}}$ & $4.1^{\text {ns }}$ & $20.3^{*}$ \\
\hline Nozzle (N) & 1 & $0.2^{\mathrm{ns}}$ & $11.3^{\mathrm{ns}}$ & $28.2^{\mathrm{ns}}$ & $692.1^{\mathrm{ns}}$ & $4,791.2 *$ & $1,285.5^{\mathrm{ns}}$ & $5.3^{\mathrm{ns}}$ & $24.6^{*}$ \\
\hline $\mathrm{V} \times \mathrm{N}(\mathrm{F})$ & 1 & $1.2^{\mathrm{ns}}$ & $48.6^{\mathrm{ns}}$ & $43.3^{\text {ns }}$ & $25.5^{\text {ns }}$ & $293.8^{\text {ns }}$ & $745.1^{\mathrm{ns}}$ & $0.1^{\mathrm{ns}}$ & $0.4^{\mathrm{ns}}$ \\
\hline $\mathrm{F} \mathrm{x}$ additional & 1 & $20.4 *$ & $3.6^{\mathrm{ns}}$ & $9.8^{\mathrm{ns}}$ & $815.4^{\mathrm{ns}}$ & $136.4^{\text {ns }}$ & $150.2^{\text {ns }}$ & $6.6^{\mathrm{ns}}$ & $4.3^{\text {ns }}$ \\
\hline Blocks & 5 & $2.7^{\mathrm{ns}}$ & $15.9^{\text {ns }}$ & $20.5^{\text {ns }}$ & $341.0^{\mathrm{ns}}$ & $621.6^{\text {ns }}$ & $645.5^{\text {ns }}$ & $4.5^{\mathrm{ns}}$ & $11.9^{*}$ \\
\hline Treatments & 4 & $5.6^{*}$ & $16.3^{\mathrm{ns}}$ & $20.5^{\mathrm{ns}}$ & $718.5^{\text {ns }}$ & $1,992.4^{*}$ & $925.6^{\mathrm{ns}}$ & $4.0^{\mathrm{ns}}$ & $12.4^{*}$ \\
\hline Residual & 20 & 2.9 & 19.3 & 18.0 & 586.2 & 327.8 & $1,109.0$ & 3.0 & 2.6 \\
\hline Total & 30 & & & & & & & & \\
\hline
\end{tabular}

* Significant at $0.05 ;{ }^{\mathrm{ns}}$ non-significant at 0.05 . 
observed similar values, but for the entire plant.

The TVI nozzle resulted in a $46.5 \%$ greater deposition than the JA nozzle on the fruits of the middle third of the plant, where most the coffee fruits were located. The application rate of $400 \mathrm{~L} \mathrm{ha}^{-1}$ resulted in a $37.3 \%$ greater dye deposition than the application rate of $200 \mathrm{~L} \mathrm{ha}^{-1}$ (Table 4).

Under adequate meteorological conditions, without the presence of excessive winds $\left(>12 \mathrm{~km} \mathrm{~h}^{-1}\right)$, fine droplets can easily follow the airflow promoted by the sprayer, what allows a good penetration on the canopy. Conversely, the weight and size of droplets allow them to pass through the crown without being deposited on the fruit or becoming lost by evaporation or draining. Similar observations were reported by An et al. (2020), for apple orchards.

Pests that attack fruits can drastically reduce production, as is the case of the coffee borer beetle Hypothenemus hampei (Ferrari 1867) (Coleoptera: Curculionidae: Scolytinae), and it is important for adopted management strategies to reduce, as much as possible, the damage of the crop (Vega et al. 2015, Souza et al. 2020). Studies on the available application technologies for the deposition of droplets on fruits are scarce; thus, this topic is considered a priority for the management of coffee borer beetles.

The results of the present study indicate that the use of coarse droplets with air induction is a viable alternative for the phytosanitary management of coffee, considering the fruit as the main target. The coffee fruit, despite its smooth texture, which favors draining, allows a good retention of the dye at both droplet sizes produced by the hydraulic nozzles investigated in this study. The same was true for the application rates investigated. However, a gradual reduction of the application rate in coffee crops is observed in the field. The reduction in the application rate, which is associated with the correct selection of

Table 4. Dye deposition on fruits of the middle third of the coffee tree, according to the spray nozzle and application rate.

\begin{tabular}{|c|c|c|}
\hline \multirow{6}{*}{ Deposition $\left(\mu \mathrm{L} \mathrm{cm}^{-2}\right)$} & \multicolumn{2}{|c|}{ Nozzle } \\
\hline & TVI-80-0075 & JA-1 \\
\hline & $60.8 a^{*}$ & $32.5 \mathrm{~b}$ \\
\hline & \multicolumn{2}{|c|}{ Application rate $\left(\mathrm{L} \mathrm{ha}^{-1}\right)$} \\
\hline & 200 & 400 \\
\hline & $35.9 \mathrm{~b}$ & $57.3 \mathrm{a}$ \\
\hline $\mathrm{CV}(\%)$ & \multicolumn{2}{|c|}{38} \\
\hline
\end{tabular}

* Means followed by different lowercase letters in the row differ by the $\mathrm{F}$ test $(\mathrm{p}>0.05)$. the droplet size, can result in applications as effective as those obtained with traditionally used volumes, i.e., $\geq 400 \mathrm{~L} \mathrm{ha}^{-1}$. Fessler et al. (2020) observed a similar reduction in the application rate in apple orchards.

Compared with the JA nozzle, the TVI nozzle resulted in a $37.0 \%$ greater loss to the ground at the Petri dish within the canopy projection. The loss was $34.0 \%$ greater for the application rate of $400 \mathrm{~L} \mathrm{ha}^{-1}$, when compared with that of $200 \mathrm{~L} \mathrm{ha}^{-1}$ (Table 5).

The application of coarse droplets with air induction resulted in a greater loss to the ground. Czaczyk et al. (2012) stated that larger droplets can protrude, break and run off leaves or other targets. Although fractionation is not normal, it may occur depending on the interaction between the target and the droplets. In this regard, Wenneker \& van de Zande (2008) stated that droplets with air induction have a higher vertical fall speed than smaller droplets owing to their size, and that they tend to accumulate in the ground near the application site. Silva et al. (2014) obtained similar results when comparing losses to the ground between nozzles with air induction and conventional conical jets in coffee cultivation. Conversely, smaller droplets may be lost due to the easy way they cross the leaf canopy, following the airflow and being directly deposited on the ground.

A higher application rate results in point runoff, due to the interaction with the target and the droplet size. The greatest depositions were observed for the fruits at the middle third of the plants, and in the Petri dish within the canopy projection on the ground, for the application rate of $400 \mathrm{~L} \mathrm{ha}^{-1}$. This greater deposition occurs at the same position where the fruits remaining from previous harvests are found, being a source of reinfestation for the coffee borer beetle.

Table 5. Dye deposition on the Petri dish on the ground within the canopy projection, as a function of the spray nozzle and application rate.

\begin{tabular}{|c|c|c|}
\hline \multirow{6}{*}{ Deposition $\left(\mu \mathrm{L} \mathrm{cm}^{-2}\right)$} & \multicolumn{2}{|c|}{ Nozzle } \\
\hline & TVI-80-0075 & JA-1 \\
\hline & $5.4 \mathrm{a}^{*}$ & $3.4 \mathrm{~b}$ \\
\hline & \multicolumn{2}{|c|}{ Application rate $\left(\mathrm{L} \mathrm{ha}^{-1}\right)$} \\
\hline & 200 & 400 \\
\hline & $3.5 \mathrm{~b}$ & $5.3 \mathrm{a}$ \\
\hline CV $(\%)$ & \multicolumn{2}{|c|}{38.6} \\
\hline
\end{tabular}


The coefficients of variation observed in the comparison tests of spray nozzles and application rates on leaves and fruits are a result of the variation in the biometry of the coffee canopy. Moreover, these result from the complexity faced by farmers when selecting appropriate application technologies to provide a greater spray deposition on leaves and fruits, with different rates and lower losses to the ground. Achieving a homogeneous application along the canopy in coffee plants is a challenge that requires the obsevation of the relationship between the application technology and plant architecture.

\section{CONCLUSIONS}

1. Electrostatic application with the SPE-2 nozzle, at a rate of $200 \mathrm{~L} \mathrm{ha}^{-1}$, results in a greater spray deposition on the upper third leaves than the hydropneumatic application with the TVI and JA nozzles, regardless of the application rate;

2. The deposition capacity in the upper third leaves do not differ for the TVI and JA nozzles, with spray volumes of 200 and $400 \mathrm{~L} \mathrm{ha}^{-1}$. However, the TVI nozzle results in a greater spray deposition on the fruits of the middle third and a greater loss to the ground than the JA nozzle;

3. The application rate of $400 \mathrm{~L} \mathrm{ha}^{-1}$ results in a greater deposition on the fruits of the middle third than the rate of $200 \mathrm{~L} \mathrm{ha}^{-1}$, but also in a greater loss to the ground.

\section{ACKNOWLEDGMENTS}

The authors would like to thank the Coordenação de Aperfeiçoamento de Pessoal de Nível Superior (Capes), Conselho Nacional de Desenvolvimento Científico e Tecnológico $(\mathrm{CNPq})$ and Fundação de Amparo à Pesquisa do Estado de Minas Gerais (Fapemig), for supporting this study.

\section{REFERENCES}

AN, Q.; LI, D.; WU, Y.; PAN, C. Deposition and distribution of myclobutanil and tebuconazole in a semidwarf apple orchard by hand-held gun and air-assisted sprayer application. Pest Management Science, v. 76, n. 12, p. 4123-4130, 2020.

AMERICAN SOCIETY OF AGRICULTURAL ENGINEERS (ASAE). ASAE S572.1: spray nozzle classification by droplet spectra. St. Joseph: ASAE, 2009.
CAMPOS, J.; GALLART, M.; LLOP, J.; ORTEGA, P.; SALCEDO, R.; GIL, E. On-farm evaluation of prescription map-based variable rate application of pesticides in vineyards. Agronomy, v. 10, n. 1, p. 2-22, 2020.

COMPANHIA NACIONAL DE ABASTECIMENTO (Conab). Acompanhamento da safra brasileira de café. Brasília, DF: Conab, 2020.

CRAUSE, D. H.; VITÓRIA, E. L. da; SOELA, D. M.; OLIVEIRA, D. A. de; BATISTA, A. G.; LACERDA, E. das G. Derivative estimate in the application of agricultural defensives in conilon coffee. Brazilian Journal of Production Engineering, v. 6, n. 4, p. 85-94, 2020.

CZACZYK, Z.; KRUGER, G.; HEWITT, A. Droplet size classification of air induction flat fan nozzles. Journal of Plant Protection Research, v. 52, n. 4, p. 415-420, 2012.

FESSLER, L.; FULCHER, A.; LOCKWOOD, D. WRIGHT, W.; ZHU, H. Advancing sustainability in tree crop pest management: refining spray application rate with a laser-guided variable-rate sprayer in apple orchards. HortScience, v. 55, n. 9, p. 1522-1530, 2020.

GIL, E.; ESCOLA, A. Design of a decision support method to determine volume rate for vineyard spraying. Applied Engineering in Agriculture, v. 25, n. 2, p. 145-151, 2009.

GITIRANANETO, J.; CUNHA, J.P. A. R. da; MARQUES, R. S.; LASMAR, O.; BORGES, E. B. Deposição de calda promovida por pulverizadores empregados na cafeicultura de montanha. Coffee Science, v. 11, n. 2, p. 267-275, 2016.

GRELLA, M.; MARUCCO, P.; BALAFOUTIS, A. T.; BALSARI, P. Spray drift generated in vineyard during under-row weed control and suckering: evaluation of direct and indirect drift-reducing techniques. Sustainability, v. 12, n. 12, e5068, 2020.

GU, C.; LIU, Z.; PAN, G.; PU, Y.; YANG, F. Optimization of working parameters for 3MGY-200 axial air-assisted sprayer in kiwifruit orchards. International Journal of Agricultural and Biological Engineering, v. 13, n. 2, p. 81-91, 2020.

KHATAWKAR, D. S.; DHALIN, D.; JAMES, P. S. Electrostatic conversion kit for conventional knapsack mist-blower: development and performance evaluation. International Journal of Current Microbiology and Applied Sciences, v. 9, n. 3, p. 2227-2242, 2020.

LI, J.; CUI, H.; MA, Y.; XUN, L.; LI, Z.; YANG, Z.; LU, H. Orchard spray study: a prediction model of droplet deposition states on leaf surfaces. Agronomy, v. 10, n. 5, e 747, 2020.

MÁQUINAS AGRÍCOLAS JACTO S. A. Bicos Jacto. 2020. Available at: https://s3.amazonaws.com/1-jacto. com.br/files/product_file_file_pt_BR_1612358357572_ 
Guia_de_bicos-jan2021-lay2.pdf. Access on: 13 Dec. 2020 .

MELO, T. L.; RAETANO, C. G.; CARDOSO, A. D.; MOREIRA, A. A.; LEITE, S. A.; CASTELLANI, M. A. Insecticide application rate in coffee crop: qualitative and quantitative aspects and efficacy of leaf miner control. Coffee Science, v. 15, e151722, 2020.

MIRANDA, G. R. B.; RAETANO, C. G.; SILVA, V. C. da; CUNHA, M. D. Q.; CARVALHO, R. H. de; PINHEIRO, J. M.; GOLÇALVES, M. de P.; REINATO, C. H. R.; PAIVA, L. C.; ARAÚJO, D. de. Avaliação dos depósitos da pulverização em frutos de cafeeiro utilizando dois equipamentos associados a diferentes volumes de calda. Revista Agrogeoambiental, v. 4, n. 1, p. 15-20, 2012.

R CORE TEAM. $R$ : a language and environment for statistical computing.Vienna: R Foundation for Statistical Computing, 2019.

SALCEDO, R.; LLOP, J.; CAMPOS, J.; COSTAS, M.; GALLART, M.; ORTEGA, P.; GIL, E. Evaluation of leaf deposit quality between electrostatic and conventional multi-row sprayers in a trellised vineyard. Crop Protection, v. 127, e104964, 2019.

SASAKI, R. S.; TEIXEIRA, M. M.; FERNANDES, H. C.; MONTEIRO, P. M. de B. Deposição e uniformidade de distribuição da calda de aplicação em plantas de café utilizando a pulverização eletrostática. Ciência Rural, v. 43, n. 9, p. 1605-1609, 2013.

SASAKI, R. S.; TEIXEIRA, M. M.; SANTIAGO, H.; MADUREIRA, R. P.; MACIEL, C. F. S.; FERNANDES, H. C. Adjuvantes nas propriedades físicas da calda, espectro e eficiência de eletrificação das gotas utilizando a pulverização eletrostática. Ciência Rural, v. 45, n. 2, p. 274-279, 2015.

SILVA, J. E. R.; CUNHA, J. P. A. R.; NOMELINI, Q. S. S. Deposição de calda em folhas de cafeeiro e perdas para o solo com diferentes taxas de aplicação e pontas de pulverização. Revista Brasileira de Engenharia Agrícola e Ambiental, v. 18, n. 12, p. 1302-1306, 2014.

SINHA, R.; RANJAN, R.; KHOT, L. R.; HOHEISEL, G. A.; GRIESHOP, M. J. Comparison of within canopy deposition for a solid set canopy delivery system (SSCDS) and an axial-fan airblast sprayer in a vineyard. Crop Protection, v. 132, e105124, 2020.

SOUZA JÚNIOR, J. M. de; RUAS, R. A. A.; DUARTE, L. O.; FARIA, V. R.; CARVALHO FILHO, A.; SANTOS JÚNIOR, C. R. Influência da densidade foliar na distribuição de calda no dossel do cafeeiro (Coffea arabica L.). Coffee Science, v. 12, n. 2, p. 216-222, 2017.

SOUZA, R. A. de; PRATISSOLI, D.; ARAÚJO JÚNIOR, L. M. de; PINHEIRO, J. de A.; SOUZA, J. F. V.; DEOLINDO, F. D.; DAMASCENA, A. P. Hypothenemus hampei ferrari (Coleoptera: Curculionidae) answer to visual and olfative stimuli in field. Coffee Science, v. 15, e151656, 2020.

TESSUM, M. W.; RAYNOR, P. C. Measuring electrostatic charge on pneumatically generated spray drops. Journal of Aerosol Science, v. 151, e105691, 2021.

TRIPATHI, H.; D'SOUZA, P. M.; TRIPATHI, A. Spray droplet characteristics of agricultural hollow cone nozzles. Journal of Pharmacognosy and Phytochemistry, v. 9, n. 2, p. 1801-1805, 2020.

VEGA, F. E.; INFANTE, F.; JOHNSON, A. J. The genus Hypothenemus, with emphasis on $H$. hampei, the coffee berry borer. In: VEGA. F. E.; HOFSTETTER, R. W. (ed.). Bark beetles: biology and ecology of native and invasive species. San Diego: Academic Press, 2015. p. 427-494.

WENNEKER, M.; van de ZANDE, J. C. Drift reduction in orchard spraying using a cross flow sprayer equipped with reflection shields (Wanner) and air injection nozzles. CIGR Journal, v. 10, n. 1, p. 1-10, 2008. 